\title{
WNT10B Gene
}

National Cancer Institute

\section{Source}

National Cancer Institute. WNT10B Gene. NCI Thesaurus. Code C20905.

This gene plays a role in signal transduction, intercellular communication and adipogenesis. It is involved in the regulation of cell fate and behavior during vertebrate development. 